\title{
Biomonitoring of Metals in Children Living in an Urban Area and Close to Waste Incinerators
}

\author{
Agostino Di Ciaula ${ }^{1,2,3, * \mathbb{C}}$, Patrizia Gentilini ${ }^{2}$, Giusy Diella ${ }^{4}$, Marco Lopuzzo ${ }^{4}$ and \\ Ruggero Ridolfi ${ }^{2}$ \\ 1 Division of Internal Medicine, Hospital of Bisceglie (ASL BAT), 76011 Bisceglie, Italy \\ 2 International Society of Doctors for Environment (ISDE), 52100 Arezzo, Italy; \\ patrizia.gentilini@villapacinotti.it (P.G.); ruggero.ridolfi@gmail.com (R.R.) \\ 3 Clinica Medica "A. Murri”, Department of Biomedical Sciences and Human Oncology, University of Bari \\ "Aldo Moro", 70124 Bari, Italy \\ 4 Department of Biomedical Science and Human Oncology, University of Study of Bari “Aldo Moro", \\ 70124 Bari, Italy; giusy.diella@uniba.it (G.D.); marcolopuzzo@gmail.com (M.L.) \\ * Correspondence: agostinodiciaula@tiscali.it
}

Received: 5 February 2020; Accepted: 10 March 2020; Published: 16 March 2020

\begin{abstract}
The impact of waste incinerators is usually examined by measuring environmental pollutants. Biomonitoring has been limited, until now, to few metals and to adults. We explored accumulation of a comprehensive panel of metals in children free-living in an urban area hosting two waste incinerators. Children were divided by georeferentiation in exposed and control groups, and toenail concentrations of 23 metals were thereafter assessed. The percentage of children having toenail metal concentrations above the limit of detection was higher in exposed children than in controls for $\mathrm{Al}, \mathrm{Ba}, \mathrm{Mn}, \mathrm{Cu}$, and $\mathrm{V}$. Exposed children had higher absolute concentrations of $\mathrm{Ba}, \mathrm{Mn}, \mathrm{Cu}$, and $\mathrm{V}$, as compared with those living in the reference area. The Tobit regression identified living in the exposed area as a significant predictor of $\mathrm{Ba}, \mathrm{Ni}, \mathrm{Cu}, \mathrm{Mn}$, and $\mathrm{V}$ concentrations, after adjusting for covariates. The concentrations of $\mathrm{Ba}, \mathrm{Mn}, \mathrm{Ni}$, and $\mathrm{Cu}$ correlated with each other, suggesting a possible common source of emission. Exposure to emissions derived from waste incinerators in an urban setting can lead to body accumulation of specific metals in children. Toenail metal concentration should be considered a noninvasive and adequate biomonitoring tool and an early warning indicator which should integrate the environmental monitoring of pollutants.
\end{abstract}

Keywords: metals; children; toenails; biomonitoring; waste; incinerators

\section{Introduction}

Waste incineration in industrial plants generates bottom and fly ashes, which are released into atmosphere after appropriate purification. This procedure, however, does not completely remove toxic chemicals from the emissions. Heavy metals (manganese, lead, cadmium, copper, nickel, mercury, thallium, and vanadium in particular) cause concerns for public health [1-5]. Fly ash emitted from waste incinerators contains large amounts of metals, leading to potential ecological risk [6,7] also due to a progressive accumulation in surrounding soils [2,8]. A study investigating heavy metals in fly ash from 15 municipal solid waste incinerators showed that metals could easily leach out, mainly due to the high content of acid soluble fraction and reducible fraction. This might generate elevated environmental risk [7]. Metals are abundantly present in particulate matter produced by waste incinerators (mainly fine and ultrafine particles, PM0.2-2.5), with dominant presence of vanadium, nickel, copper, zinc, cadmium, and lead in fine particles and with magnesium, aluminum and thallium in coarse particles [5]. Fine particles emitted from waste incinerators have elevated content of heavy 
metals and are more cytotoxic than those emitted from biomass incineration [9], thus contributing to human toxicity [10].

Metals can enter the human body through different routes such as dermal contact, inhalation, and ingestion [11,12]. Children are particularly vulnerable, in terms of biological effects, when exposed to metal pollution [13-17], mainly due to oxidative damage following chronic exposure [18,19]. In pediatric age, the body burden of metals has been linked with a number of pathologic conditions including nononcologic diseases (i.e., altered growth and development [20], obesity [21,22], and neurologic [23-25], cognitive [26], and respiratory [19,27] disorders) and cancer [28-30].

A recent study characterizing the distribution of heavy metals in ambient air particles (PM1, PM2.5, PM10) emitted from a municipal waste incinerator, indicated that children living close to this industrial plant had a high noncarcinogenic risk and a high lifetime carcinogenic risk following exposure to toxic metals bound to the emitted particles [28]. Several studies explored the concentration of heavy metals (mainly lead, cadmium, mercury, nickel, and chromium) in adults exposed to emissions from waste incinerators [31-36]. However, in the majority of cases a limited number of metals have been considered, and the sampling procedures were on blood and/or urine, thus mainly representing shortrather than long-term exposure [37-40]. Similarly, previous biomonitoring studies in exposed children only determined the body burden of few trace elements (mainly manganese [3], chromium, lead, and cadmium [41-43]), not considering the wide panel of metals [1,5] emitted by waste incinerators.

Thus, studies investigating the long-term accumulation of multiple metals in children living close to waste incinerators are still lacking. Furthermore, noninvasive biomonitoring tools able to determine, in this age class, the health risk deriving from the discharge of hazardous pollutants into the environment are strongly needed. In fact, human biomonitoring has been proposed as more useful to assess possible health effects than environmental monitoring [44,45]. In this respect, human nails have been frequently employed for the assessment of metal exposure of various origin [46], have been used in pediatric age [47-51], and have been indicated as suitable indicators of long-term exposures [52,53].

\section{Methods}

\subsection{Study Design}

The aim of the present study was to measure the body burden of a wide panel of metals (23 different elements, see Section 2.4) in children living in an urban setting, at different distances from two waste incinerators. According to previous evidence, the concentration of metals in toenails was employed as an indicator of chronic environmental exposure [37-39,52,53], adjusting results for possible confounders.

\subsection{Study Population and Area}

A public campaign served to explain the aims of the study. Subsequently, a total of 220 children (128 males, age range 6-9 years) were enrolled in the city of Forlì (Emilia-Romagna region, Northern Italy, 117,946 residents in 2017) from December 2016 to March 2017, after parents signed informed consent. Children also agreed to participate as volunteers.

Inclusion criteria were living at the same address in the last 6 months before enrollment, and the presence of a signed informed consent.

Subjects with previously known diseases were excluded from the study.

In the urban study area, two incinerators are located about $200 \mathrm{~m}$ from each other: a municipal solid waste incinerator (total capacity $100,000 \mathrm{Nm}^{3} / \mathrm{h}$ ), and a hospital waste incinerator (total capacity of $21,500 \mathrm{Nm}^{3} / \mathrm{h}$ ). Besides these two plants, according to the official emission inventories, the remaining sources of air pollution in the explored area are vehicular traffic (urban traffic, two major roadways) and domestic heating during cold season.

All enrolled children were georeferentiated. According to previous studies $[28,33,41,54-57]$ and to results from a dispersion model specifically assessed for the two incinerators [54], exposed subjects 
were considered those living within a $3 \mathrm{~km}$ radius circle around the two plants, with the circle centered in the middle distance between the two (Figure 1).

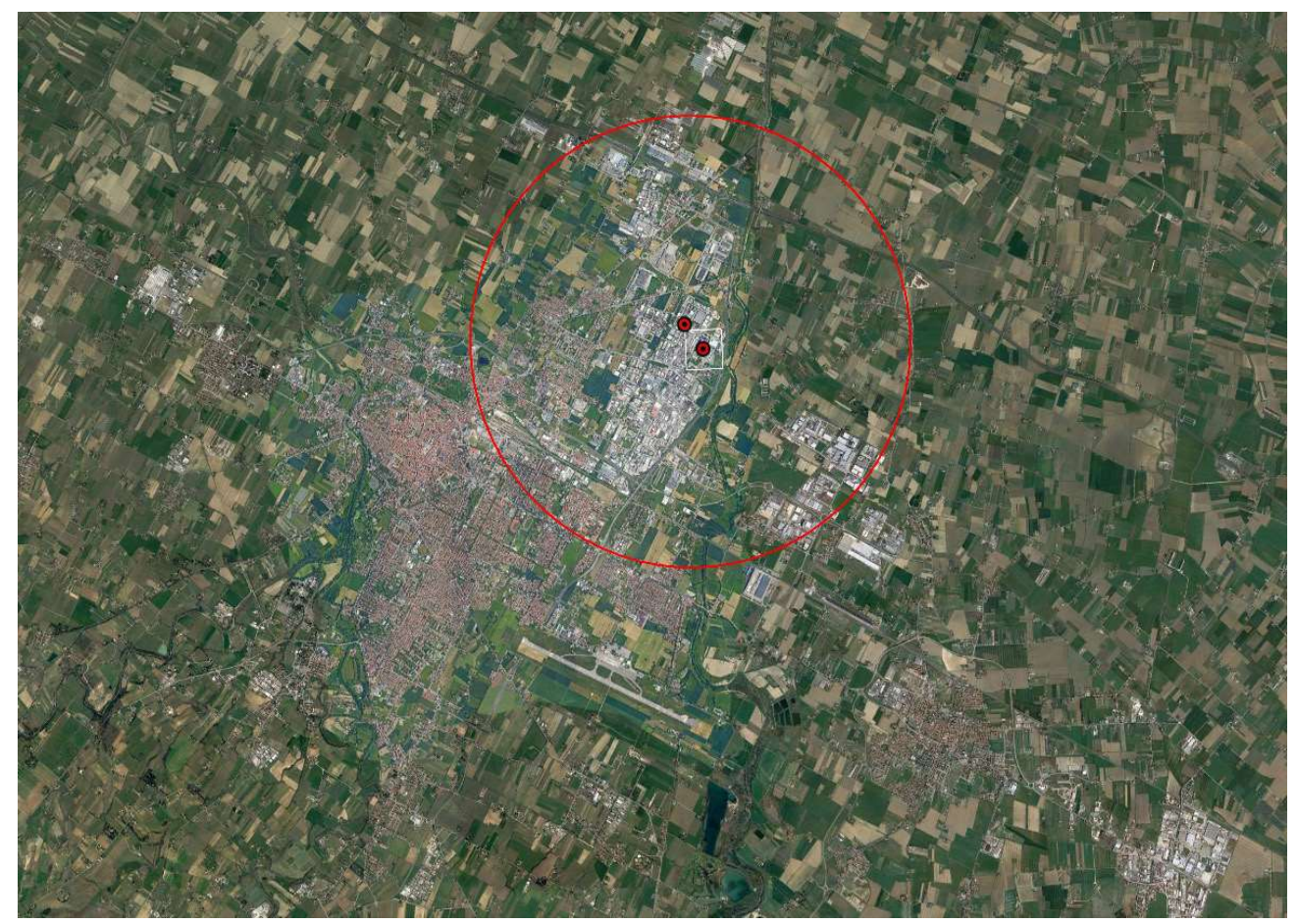

Figure 1. Study area around incinerators (filled circles), in the city of Forlì (Emilia-Romagna, Northern Italy). Exposed subjects considered were 62 children living within a $3 \mathrm{~km}$ radius circle around the two incinerators, with the circle centered in the middle of the distance between the two plants. A total of 158 enrolled children were residents in the remaining city areas (reference area).

Subjects in the reference area (controls) were the residents living outside this circle.

The Romagna Ethical Committee (CEROM) approved the study protocol. The initiative was entirely self-financed with popular events for fundraising or voluntary donations. Written informed consent was signed by both parents.

\subsection{Assessment of Potential Confounders}

A questionnaire served to explore further possible environmental conditions or personal behaviors able to influence the concentration of metals in toenails. Covariates included residential proximity (i.e., less than $300 \mathrm{~m}$ ) to busy roads, previous orthodontic treatments, regular practice of outdoor sports, hobbies involving the use of chemicals, exposure to passive smoke, and regular consumption of locally grown vegetables. The questionnaire was administered to parents for self-compilation.

\subsection{Nail collection, Sample Preparation, and Analysis}

Toenails were selected for sampling as preferential to fingernails due to a minor risk of external contamination [58]. The procedures for toenail collection, sample preparation, and analysis have been extensively employed in previous studies [47,48,59-67].

Toenails were clipped using ceramic blade to avoid possible contamination. Samples were thereafter stored in a $10 \mathrm{~mL}$ polypropylene tube for subsequent analysis, and scissors were cleaned with a light-acid solution. Toenails were examined according to a standardized technique [68]. Briefly, samples were immersed in a 70\% ethanol solution without stirring or sonication for a period of $10 \mathrm{~min}$, to reduce the risk of microbiological contamination. Exogenous impurities were removed by a 
multistep washing procedure with acetone and Milli-Q purified water, and the cleaned samples were kept at room temperature for a period from 24 to $48 \mathrm{~h}$ for drying.

The dry samples were weighed, and the concentration of 23 elements (Aluminum (Al), Antimony (Sb), Arsenic (As), Barium (Ba), Beryllium (Be), Boron (B), Cadmium (Cd), Chromium (Cr), Cobalt (Co), Iron (Fe), Manganese (Mn), Mercury (Hg), Molybdenum (Mo), Nickel (Ni), Lead (Pb), Copper (Cu), Selenium (Se), Thallium (Tl), Thorium (Th), Tungsten (W), Uranium (U), Vanadium (V) and Zinc (Zn)) was subsequently calculated, using inductively coupled plasma mass spectrometry (ICP-MS) and the EPA 6020A 2007 method.

\subsection{Statistical Analysis}

Frequencies of categorical variables and means and standard errors of continuous variables were calculated. The Wilcoxon test or the chi-squared test were employed to compare differences among groups. Correlations were tested using the Spearman's rank correlation coefficient. Tobit regression models were employed to examine the association between the concentration of metals and potential influencing factors. Tobit regression was also used to accommodate the left-censored nature of values, due to the presence of samples with metal concentration below the limit of detection [69]. Metal concentrations were log-transformed to meet the normal assumption [70]. $P$ values $<0.05$ were considered statistically significant.

Analyses were performed using R software version 3.5.1 (R Project for Statistical Computing, available from https://www.r-project.org/).

\section{Results}

According to georeferentiation, totals of 62 and 158 children were residents within $3 \mathrm{~km}$ from the incinerators (exposed area) and in the control area, respectively.

The concentrations of Mo, Tl, W, and $\mathrm{U}$ were lower than the limit of detection (LOD) in all collected toenail samples, irrespective of residence (Table 1 and Figure 2). The concentrations of As, Co, and Th were above the LOD in three $(4.8 \%)$, one $(1.6 \%)$ and two $(3.2 \%)$ subjects living in the exposed area, respectively, but in none of those living in the reference areas. Conversely, Bo was only measurable in one subject living in the reference area.

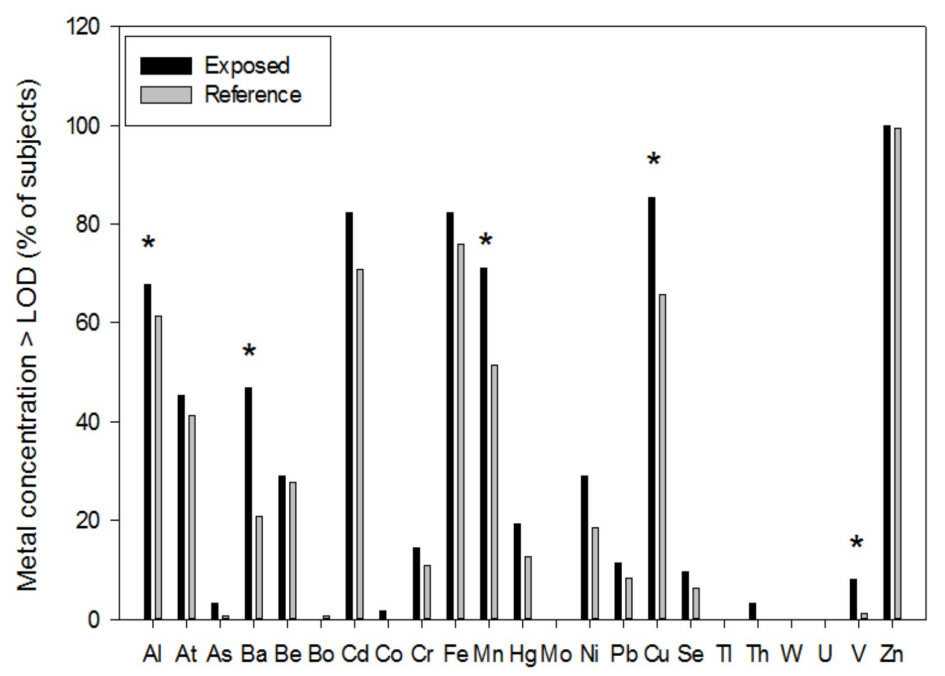

Figure 2. Proportion of children with metal concentration in toenails above the limit of detection (LOD). Children living within a $3 \mathrm{~km}$ radius from the two incinerators were considered exposed $(\mathrm{n}=62)$. Children in the reference area $(n=158)$ were those living in the remaining city areas. Asterisks indicate $p<0.01$ (chi-squared test). 
As shown in Figure 2, the percentage of children with toenail metal concentrations above the LOD tended to be higher in those living in the exposed than in those living in the reference area in all cases, with significantly higher proportions for $\mathrm{Al}(67.7 \%$ vs. $61.4 \%$, respectively), Ba (46.8\% vs. $20.9 \%)$, Mn (71\% vs. $51.3 \%)$, Cu (85.5\% vs. $65.8 \%)$ and V (8.1\% vs. $1.3 \%)$.

Table 1 shows the absolute concentrations of metals measured in the two groups of children. Children living within $3 \mathrm{~km}$ around the incineration plants had significantly higher concentrations of $\mathrm{Ba}, \mathrm{Mn}, \mathrm{Cu}$, and $\mathrm{V}$, as compared with those living in reference area. On average, the concentrations of these metals were, respectively, 5.5, 1.8, 1.3 and 9.5 times higher in children living in the exposed area than those in the control area.

According to results of the Tobit regression (Table 2), living in the exposed area was a significant predictor of $\mathrm{Ba}, \mathrm{Ni}, \mathrm{Cu}, \mathrm{Mn}$, and $\mathrm{V}$ concentrations, after adjusting for covariates. The analysis of covariates also showed influencing effects of previous orthodontic treatments on $\mathrm{Ba}$ and $\mathrm{Cu}$ concentrations and of exposure to passive smoke on Ba concentrations. However, the proportions of children with previous orthodontic treatments (9.7\% in exposed, $10.1 \%$ in reference area, $p=$ NS) or exposed to passive smoke (3.2\% in exposed, $6.3 \%$ in reference area, $p=N S$ ) were similar in the two groups of children.

Table 1. Absolute concentrations of metals $(\mu \mathrm{g} / \mathrm{g})$ in toenails from children living within a $3 \mathrm{~km}$ radius circle around the two incinerators (exposed area) or in the reference area.

\begin{tabular}{|c|c|c|c|}
\hline Metal & $\begin{array}{l}\text { Exposed Area } \\
\quad(n=62)\end{array}$ & $\begin{array}{l}\text { Reference Area } \\
\quad(n=158)\end{array}$ & $p$ \\
\hline $\mathrm{Al}$ & $166.48 \pm 50.42$ & $103.24 \pm 11.01$ & NS \\
\hline At & $0.07 \pm 0.02$ & $0.10 \pm 0.02$ & NS \\
\hline As & $0.01 \pm 0.01$ & 0.00 & NS \\
\hline $\mathrm{Ba}$ & $11.95 \pm 9.01$ & $2.15 \pm 0.87$ & $<0.0002$ \\
\hline $\mathrm{Be}$ & $0.03 \pm 0.01$ & $0.03 \pm 0.005$ & NS \\
\hline Bo & 0.00 & $0.15 \pm 0.15$ & NS \\
\hline $\mathrm{Cd}$ & $0.03 \pm 0.004$ & $0.07 \pm 0.02$ & NS \\
\hline Co & $0.04 \pm 0.04$ & 0.00 & NS \\
\hline $\mathrm{Cr}$ & $4.82 \pm 3.88$ & $1.28 \pm 0.44$ & NS \\
\hline $\mathrm{Fe}$ & $360.08 \pm 126.57$ & $164.49 \pm 21.06$ & NS \\
\hline $\mathrm{Mn}$ & $4.40 \pm 1.23$ & $2.47 \pm 0.35$ & $<0.05$ \\
\hline $\mathrm{Hg}$ & $0.05 \pm 0.01$ & $0.06 \pm 0.02$ & NS \\
\hline Mo & 0.00 & 0.00 & NS \\
\hline $\mathrm{Ni}$ & $2.23 \pm 1.51$ & $0.43 \pm 0.18$ & NS \\
\hline $\mathrm{Pb}$ & $0.32 \pm 0.13$ & $0.95 \pm 0.47$ & NS \\
\hline $\mathrm{Cu}$ & $6.34 \pm 0.70$ & $4.74 \pm 0.36$ & $<0.05$ \\
\hline Se & $0.01 \pm 0.005$ & $0.01 \pm 0.003$ & NS \\
\hline $\mathrm{Tl}$ & 0.00 & 0.00 & NS \\
\hline Th & $0.01 \pm 0.01$ & 0.00 & NS \\
\hline W & 0.00 & 0.00 & NS \\
\hline $\mathrm{U}$ & 0.00 & 0.00 & NS \\
\hline $\mathrm{V}$ & $0.19 \pm 0.11$ & $0.02 \pm 0.02$ & $<0.02$ \\
\hline $\mathrm{Zn}$ & $96.27 \pm 9.42$ & $95.30 \pm 3.09$ & NS \\
\hline
\end{tabular}

Legend: values are expressed as means and standard errors. NS, not significant. 
Table 2. Results of Tobit regression model on metal concentrations in toenails from children living within a $3 \mathrm{~km}$ radius circle around the two incinerators (exposed area) or in the reference area, and the effect of covariates.

\begin{tabular}{|c|c|c|c|c|c|}
\hline & Ba & $\mathrm{Ni}$ & $\mathrm{Cu}$ & Mn & V \\
\hline Exposed vs. Reference & $\begin{array}{c}0.76^{* * *} \\
(0.4 \text { to } 1.1)\end{array}$ & $\begin{array}{c}0.31 * \\
(0.05 \text { to } 0.6)\end{array}$ & $\begin{array}{c}0.22 * * \\
(0.06 \text { to } 0.4)\end{array}$ & $\begin{array}{c}0.2 * \\
(0.06 \text { to } 0.4)\end{array}$ & $\begin{array}{c}1.08^{*} \\
(0.2 \text { to } 2.0)\end{array}$ \\
\hline $\begin{array}{l}\text { Residential proximity } \\
\text { to busy roads }\end{array}$ & $\begin{array}{c}-0.13 \\
(-0.5 \text { to } 0.2)\end{array}$ & $\begin{array}{c}-0.18 \\
(-0.4 \text { to } 0.05)\end{array}$ & $\begin{array}{c}0.09 \\
(-0.03 \text { to } 0.2)\end{array}$ & $\begin{array}{c}-0.1 \\
(-0.3 \text { to } 0.01)\end{array}$ & $\begin{array}{c}-0.1 \\
(-0.8 \text { to } 0.5)\end{array}$ \\
\hline $\begin{array}{l}\text { Orthodontic } \\
\text { treatments }\end{array}$ & $\begin{array}{c}-0.87^{*} \\
(-1.6 \text { to }-0.2)\end{array}$ & $\begin{array}{c}-0.08 \\
(-0.5 \text { to } 0.3)\end{array}$ & $\begin{array}{c}0.3^{*} \\
(0.04 \text { to } 0.5)\end{array}$ & $\begin{array}{c}-0.05 \\
(-0.3 \text { to } 0.2)\end{array}$ & $\begin{array}{c}0.8 \\
(-0.1 \text { to } 1.7)\end{array}$ \\
\hline Outdoor sports & $\begin{array}{c}0.13 \\
(-0.2 \text { to } 0.5)\end{array}$ & $\begin{array}{c}0.08 \\
(-0.2 \text { to } 0.3)\end{array}$ & $\begin{array}{c}0.006 \\
(-0.1 \text { to } 0.2)\end{array}$ & $\begin{array}{c}0.1 \\
(-0.03 \text { to } 0.3)\end{array}$ & $\begin{array}{c}-0.3 \\
(-1.0 \text { to } 0.4)\end{array}$ \\
\hline $\begin{array}{l}\text { Hobbies involving } \\
\text { chemicals }\end{array}$ & $\begin{array}{c}0.08 \\
(-0.2 \text { to } 0.4) \\
\end{array}$ & $\begin{array}{c}-0.07 \\
(-0.3 \text { to } 0.2)\end{array}$ & $\begin{array}{c}-0.1 \\
(-0.3 \text { to } 0.006)\end{array}$ & $\begin{array}{c}0.06 \\
(-0.09 \text { to } 0.2)\end{array}$ & $\begin{array}{c}-0.2 \\
(-0.9 \text { to } 0.5)\end{array}$ \\
\hline Passive smoke & $\begin{array}{c}0.8 * \\
(0.3 \text { to } 1.4) \\
\end{array}$ & $\begin{array}{c}0.36 \\
(-0.07 \text { to } 0.8) \\
\end{array}$ & $\begin{array}{c}0.09 \\
(-0.2 \text { to } 0.4) \\
\end{array}$ & $\begin{array}{c}0.2 \\
(-0.2 \text { to } 0.5)\end{array}$ & $\begin{array}{c}1.0 \\
(-0.2 \text { to } 2.2)\end{array}$ \\
\hline $\begin{array}{l}\text { Consumption of locally } \\
\text { grown vegetables }\end{array}$ & $\begin{array}{c}0.1 \\
(-0.06 \text { to } 0.3)\end{array}$ & $\begin{array}{c}0.04 \\
(-0.08 \text { to } 0.2)\end{array}$ & $\begin{array}{c}-0.008 \\
(-0.08 \text { to } 0.07)\end{array}$ & $\begin{array}{c}0.09 \\
(0.01 \text { to } 0.2)\end{array}$ & $\begin{array}{c}0.005 \\
(-0.4 \text { to } 0.4)\end{array}$ \\
\hline Constant & $\begin{array}{c}0.05 \\
(-0.1 \text { to } 0.2)\end{array}$ & $\begin{array}{c}-0.2 \\
(-0.5 \text { to }-0.1)\end{array}$ & $\begin{array}{c}-0.59 \\
(-0.7 \text { to }-0.5)\end{array}$ & $\begin{array}{c}-0.5 \\
(-0.6 \text { to }-0.4)\end{array}$ & $\begin{array}{c}-0.04 \\
(-0.6 \text { to } 0.5)\end{array}$ \\
\hline
\end{tabular}

Legend: only significant results (metal concentration) are presented. Metal concentrations were log-transformed to meet the normal assumption. Results ( $\beta$ coefficients and $95 \%$ confidence intervals) have been adjusted for covariates and consider the left-censored data present in metals distribution. ${ }^{*} p<0.05,{ }^{* *} p<0.02,{ }^{* * *} p<0.001$.

Considering the whole group of subjects, the Spearman's correlation matrix showed that Ba, Mn, $\mathrm{Ni}$, and $\mathrm{Cu}$ (but not $\mathrm{V}$ ) were correlated with each other, suggesting the possibility of a common source of emission (Table 3).

Table 3. Spearman's correlation matrix considering the toenail concentrations of $\mathrm{Ba}, \mathrm{Mn}, \mathrm{Ni}, \mathrm{Cu}$, and $\mathrm{V}$ in the whole group of enrolled children $(n=220)$.

\begin{tabular}{cccccc}
\hline & $\mathbf{B a}$ & $\mathbf{M n}$ & $\mathbf{N i}$ & $\mathbf{C u}$ & $\mathbf{V}$ \\
\hline $\mathbf{B a}$ & - & 0.45 & 0.36 & 0.23 & 0.13 \\
\hline $\mathbf{M n}$ & - & $<\mathbf{0 . 0 0 0 0 0 1}$ & $\boldsymbol{< 0 . 0 0 0 0 0 1}$ & $\mathbf{0 . 0 0 0 6}$ & 0.059 \\
\hline & 0.45 & - & 0.36 & 0.37 & 0.09 \\
\hline $\mathbf{N i}$ & 0.000001 & - & $<\mathbf{0 . 0 0 0 0 0 1}$ & $<\mathbf{0 . 0 0 0 0 0 1}$ & 0.17 \\
\hline $\mathbf{C u}$ & 0.36 & 0.36 & - & 0.23 & 0.09 \\
\hline $\mathbf{V}$ & 0.000001 & $<\mathbf{0 . 0 0 0 0 0 1}$ & - & $\mathbf{0 . 0 0 0 6}$ & 0.18 \\
\hline & 0.0006 & 0.37 & 0.23 & - & 0.02 \\
\hline & 0.13 & 0.09 & 0.09 & 0.02 & 0.82 \\
\hline & 0.059 & 0.16 & 0.18 & 0.82 & -
\end{tabular}

Legend: data are Spearman correlation coefficients (rho, normal text) and $p$-values (in italic). Significant $p$-values are marked in bold.

\section{Discussion}

Results from the present study show for the first time an increased body burden of specific metals in children free-living in an urban area and exposed to emissions from waste incinerators, as compared with controls. 
We used toenails as a biomarker of exposure to metals. Metals bind keratin proteins maintaining a stable concentration over time, independently from changes in metabolic activities [38,39]. The slow rate of growth of toenails (on average $1.62 \mathrm{~mm} / \mathrm{month}$ ) [37] allows to evaluate longer term exposure [37], as compared with blood or urine [38-40]. Few studies evaluated the correlation between the concentration of metals in nails and in other biological matrices, with variable results [40] probably due to the different time windows that can be explored using nails (6-12 months earlier [37,40,67,71,72]), blood (2-3 h [73]), and urine (3-4 days [74]). Positive correlations have been documented between concentration in toenails, urine, and blood in the case of Mn [75] which, in the present study, has been found in higher concentration in exposed children than in controls. Of note, positive correlations have been demonstrated between the concentrations of metals in toenails and in environmental matrices such as dust $[61,71,76,77]$, soil $[61,63,77,78]$, and water $[63,79]$, confirming the adequacy of toenail as a biomarker of environmental exposure.

In exposed subjects, we found metals that, conversely, were in all cases below the LOD (As, Co, and $\mathrm{Th}$ ) or were present in significantly lower concentrations (in particular $\mathrm{Ba}, \mathrm{Mn}, \mathrm{Cu}$, and $\mathrm{V}$ ) in children living in the reference area. Living within a $3 \mathrm{~km}$ circle from waste incinerators was a significant predictor of $\mathrm{Ba}, \mathrm{Ni}, \mathrm{Cu}, \mathrm{Mn}$, and $\mathrm{V}$ concentrations, after adjusting for covariates. The presence, in our study, of a correlation between the concentrations of these metals (with the exception of $\mathrm{V}$ ) points to a probable common source of exposure. A recent health-risk assessment study indicated that ambient air around $3 \mathrm{~km}$ from a municipal waste incinerator had more PM1, PM2.5, and PM10 particles than general nonpolluted air [28]. The cited study also showed high noncarcinogenic risk and lifetime carcinogenic risk for children, derived from incinerator-emitted particle-bound toxic metals [28].

Our results are in line with a previous study determining air pollutants collected downwind from an Italian incinerator and showing that $\mathrm{Mn}, \mathrm{Cu}, \mathrm{Ba}$, and $\mathrm{V}$ were among metals with the highest concentrations in both the fine and coarse fractions of the particulate matter [1]. In a study assessing the short-term oxidative potential of urban particulate matter in adult nonsmoking volunteers, several metals present in coarse, fine, and ultrafine PM (including $\mathrm{Ba}, \mathrm{Cu}, \mathrm{Ni}$, and $\mathrm{V}$ ) were significantly associated with increased levels of biomarkers of systemic inflammation, oxidative stress, and neural function. Ba, in particular, induced a significant increment $(+11 \%$ at $1 \mathrm{~h},+14 \%$ at $21 \mathrm{~h}$ postexposure) of L1(UCHL1) (traumatic brain injury marker ubiquitin C-terminal hydrolase L1); Cu exposure increased $(+14 \%$ at $1 \mathrm{~h})$ levels of the DNA oxidation marker 8-hydroxy-deoxy-guanosine; urinary cortisol increased by $88 \%$ after exposure to $\mathrm{V}$, and the blood inflammatory marker VEGF (vascular endothelia growth factor) increased by $5.3 \% 1 \mathrm{~h}$ after Ni exposure [80].

Toenail concentration of Mn has been frequently studied both in children [47-50] and in adults [40], with an LOD ranging from 0.001 [81] to $0.33 \mu \mathrm{g} / \mathrm{g}$ [66] and values usually below $10 \mu \mathrm{g} / \mathrm{g}$ [40]. The highest Mn toenail concentrations have been found in subjects living near a highly industrialized city in Pakistan (average value $52.1 \mu \mathrm{g} / \mathrm{g}$ ) [82] and in highly polluted areas in Cambodia (average concentration $43.9 \mu \mathrm{g} / \mathrm{g}$ ) [66]. In our study, the average Mn concentration recorded in toenails from exposed children $(4.4 \mu \mathrm{g} / \mathrm{g})$ was slightly higher than that previously reported in pediatric age $(3.57 \mu \mathrm{g} / \mathrm{g}$, weighted means) in an analysis of pooled literature [47].

In Brazilian children aged 11-16 years and living in an urban area, fingernail metal concentrations are linked with the degree of urbanization (i.e., population density) and with the extent of vehicular traffic. This explains about half $(50.8 \%)$ of the variance in metal concentration. In the cited study, the average Mn nail concentration measured in subjects living in the area with the highest population density was $1.3 \mu \mathrm{g} / \mathrm{g}$, a value about 3.3 times lower than the mean Mn concentration detected in our series of exposed children [48]. This difference could be due, at least in part, to the coexisting exposure in our series of exposed children to vehicular traffic and industrial pollution. In fact, the average $\mathrm{Mn}$ nail concentration measured in our study in children living in the reference area $(2.47 \mu \mathrm{g} / \mathrm{g})$ and mainly exposed to vehicular traffic was close to that reported in Brazilian children.

According to a previous observation, urinary concentrations of $\mathrm{Mn}$ are inversely related to the distance of residence from a municipal solid waste incinerator, and are directly linked with the exposure 
to particulate matter [31]. Mn was present at the highest level among heavy metals in particulate matter collected downwind of an Italian incinerator [1]. Mn has also been described as the metal with the highest concentration in soil $[2,83]$ and with the second highest concentration in air (following $\mathrm{Cu}$ [83] or $\mathrm{Pb}$ [28]) around a solid waste incinerator.

Inhaled Mn can cross the blood-brain barrier and can enter the brain through axonal transport from the olfactory bulb to the cerebral cortex [84]. Children might be particularly at risk from Mn inhalation. In children aged 7-9 years living in East Liverpool (Ohio), a site with a hazardous waste incinerator and a manganese processor, a link has been shown between blood/hair Mn levels and neurological effects (altered IQ score) after adjusting for potential confounders [3].

In our series of enrolled children, the average Mn concentration in toenails from exposed subjects $(4.4 \mu \mathrm{g} / \mathrm{g})$ was 3 times higher than that measured $(1.43 \mu \mathrm{g} / \mathrm{g})$ in toenails from 225 school-age children (7-12 years) living in a Brazilian industrial region. In this group of subjects, a relationship has been demonstrated between high toenail Mn concentrations and the increased risk of intellectual deficit linked to $\mathrm{Pb}$ exposure, although the exposure was low (only $1.8 \%$ of children were above the CDC reference value of $5 \mu \mathrm{g} / \mathrm{dL}$ ) [49]. A study assessing Mn accumulation in children aged 7-12 years and living near a ferro-manganese alloy plant indicated toenail $\mathrm{Mn}$ as a biomarker of environmental exposure, associating the burden of this metal in exposed subjects with disrupting neurobehavior. Of note, in exposed children, the median Mn toenail concentration recorded in the cited study was about 5 times lower than the mean value $(0.84 \mu \mathrm{g} / \mathrm{g})$ observed in our study [50].

Studies exploring the specific concentrations of heavy metals in air samples collected around a Spanish municipal solid waste incinerator showed that the highest concentration was registered for $\mathrm{Cu}[83,85]$. Previous studies assessed nail $\mathrm{Cu}$ concentrations both in adults $[40,86]$ and in children [47], indicating an LOD ranging, for this metal, from 0.009 to $0.12 \mu \mathrm{g} / \mathrm{g}$, with values usually below $10 \mu \mathrm{g} / \mathrm{g}$ [40]. The highest $\mathrm{Cu}$ concentration in nails (average value $26.2 \mu \mathrm{g} / \mathrm{g}$ ) has been recorded in subjects living in rural areas near a highly industrialized city in Pakistan [82]. The average $\mathrm{Cu}$ toenail concentration recorded in our series of exposed children $(6.34 \mu \mathrm{g} / \mathrm{g})$ was slightly higher than that $(5.66 \mu \mathrm{g} / \mathrm{g})$ measured in nails from Arab-American children living in a highly industrialized US area [47].

An increased $\mathrm{Cu}$ body burden has been related with increased oxidative stress secondary to the reduction of antioxidant enzyme activity and the generation of reactive oxygen species (ROS). These events are able to promote DNA damage, favoring the onset of cancer [87]. A recent study compared metal concentrations in nails from adults with non-Hodgkin or Hodgkin lymphoma, showing higher $\mathrm{Cu}$ levels in both groups of patients as compared with healthy controls. In the cited study, the mean nail $\mathrm{Cu}$ concentration in controls $(4.8 \mu \mathrm{g} / \mathrm{g})$ was very similar to that observed in our series of children living in the control area $(4.74 \mu \mathrm{g} / \mathrm{g})$, and $\mathrm{Cu}$ concentrations in nail samples from lymphoma patients (7.36 and $7.76 \mu \mathrm{g} / \mathrm{g}$ in non-Hodgkin and Hodgkin lymphoma, respectively) were only slightly higher that the average Cu concentration recorded, in our study, in exposed children (6.34 $\mu \mathrm{g} / \mathrm{g})$ [86].

Of note, children's exposure to $\mathrm{Cu}$ has also been linked with nononcologic conditions such as neurologic disorders [23-25] and obesity [22]. Significantly higher blood $\mathrm{Cu}$ concentrations have been found in obese children, as compared with healthy controls [88,89]. Additionally, a large cross-sectional survey on US children and adolescents demonstrated a strong association between the highest quartile of blood $\mathrm{Cu}$ concentration and obesity [22].

Ba is not essential in human nutrition, but, as mainly suggested by animal studies, health effects secondary to chronic Ba exposure are possible in humans, although results from epidemiologic studies are still scarce [90], as are biomonitoring reports [91]. The main routes of nonoccupational human exposure to Ba are the ingestion of contaminated food and/or water [90]. However, this metal is also frequently detected in particulate matter produced by several industrial combustion processes, including waste incineration $[1,90]$.

In a group of 126 healthy Brazilian children living in an urban area (Porto Alegre) [51], mean Ba concentration in nails $(5.6 \mu \mathrm{g} / \mathrm{g})$ was 2.6-fold higher than that observed, in our study, in children living in the control area $(2.15 \mu \mathrm{g} / \mathrm{g})$, but 2-fold lower than that recorded in our exposed children $(11.9 \mu \mathrm{g} / \mathrm{g})$. 
The average concentration of Ba observed in toenails from our series of exposed children was also about 9 times higher than the average Ba nail concentration measured in Arab-American children living in a highly industrialized US area $(1.28 \mu \mathrm{g} / \mathrm{g})$ [47] and 3.7 times higher than that reported in a series of 145 adults $(3.21 \mu \mathrm{g} / \mathrm{g})$, in whom a significant association between Ba levels in toenails and hearing loss at $8 \mathrm{kHz}$ and $12 \mathrm{kHz}$ was demonstrated after adjustment for sex, age, body mass index, and smoking [92].

Recently, Ba exposure during pregnancy (assessed by measuring Ba concentrations in maternal hair and in fetal placenta) has been dose-dependently linked with the risk of congenital heart defects in offspring, underlying health hazards deriving from prenatal and transplacental exposure to this metal [93]. Furthermore, data from the National Health and Nutrition Examination Survey (NHANES 1999-2011) found, in a large cohort of US children aged 6-19 years, a strong association between Ba exposure (urinary Ba concentration) and obesity [21].

Several studies measured the concentration of $\mathrm{V}$ in nails $[40,47,48,81,94,95]$, reporting an LOD of $0.001 \mu \mathrm{g} / \mathrm{g}$ [81], an inverse relation with age [47,94,95], and values generally lower than $1 \mu \mathrm{g} / \mathrm{g}$ [40]. This was also the case of toenail $\mathrm{V}$ concentration measured in the exposed children from our study $(0.19 \mu \mathrm{g} / \mathrm{g})$. This concentration, however, was higher (about double) than that recorded in nails from Arab-American children living in a highly industrialized US area $(0.09 \mu \mathrm{g} / \mathrm{g})$ [47], in a series of Brazilian children living in an urban area $(0.08 \mu \mathrm{g} / \mathrm{g})$ [48], and as compared with the average concentration $(0.11 \mu \mathrm{g} / \mathrm{g})$ derived from pooled literature values in pediatric age [47].

In the present study, toenail concentration of $\mathrm{V}$ was higher in children living in the exposed area than in those in the control area. However, there was no relationship between toenail concentration of $\mathrm{V}$ and concentrations of $\mathrm{Ba}, \mathrm{Mn}, \mathrm{Ni}$, and $\mathrm{Cu}$ that, conversely, were correlated with each other. This result could be due to a local source of anthropogenic emission of $\mathrm{V}$ different from the two incinerator plants. On the other hand, it is also possible that the same plants generate $\mathrm{V}$, but through combustion processes not involving solid waste. In fact, air concentrations of $\mathrm{V}$ have been used as an indicator of emissions from oil combustion [96-98], and it has been suggested that burning waste oil in incinerators or using oil for providing power in incinerator plants can generate $\mathrm{V}$ emissions [98]. Vanadium has been measured in air samples around a Spanish incinerator [85], and a cross-sectional study assessing metal concentrations in spot urine samples from subjects living within $4 \mathrm{~km}$ from an Italian incinerator showed, in exposed subjects, $\mathrm{V}$ levels higher than the reference value for the Italian population [32].

According to our results, living in the exposed area was a significant predictor of toenail $\mathrm{Ni}$ concentrations, which were related with toenail concentrations of $\mathrm{Ba}, \mathrm{Mn}$, and $\mathrm{Cu}$. Data also showed a trend towards an increased toenail concentration of $\mathrm{Ni}$ in children living in the exposed area compared to those in the control area.

$\mathrm{Ni}$ has been detected in both air and soil samples collected around a Spanish municipal solid waste incinerator [85], and a study in Taiwan showed that the burden of this metal in the local airborne particles was highly influenced by the stack emission of the local incinerator [4]. Additionally, a study analyzing samples of particulate matter collected in proximity of a Chinese municipal solid waste incinerator described fine particles as dominant, as compared with coarse and ultrafine particles, and anthropogenic metal elements (including $\mathrm{Ni}, \mathrm{Cu}, \mathrm{V}$ ) predominantly concentrated in fine particles [5].

The average toenail concentration of Ni measured, in our study, in exposed children $(2.23 \mu \mathrm{g} / \mathrm{g})$, was slightly higher than that $(1.8 \mu \mathrm{g} / \mathrm{g})$ found in Brazilian children living in an urban area with high population density [48], but much lower than the mean concentration detected in Arab-American children living in an urban setting in a highly industrialized area $(45.18 \mu \mathrm{g} / \mathrm{g})$ [47].

In children, the exposure to $\mathrm{Ni}$ in particulate matter is negatively associated with indices of lung function. Ni vehiculated by PM10, in particular, has been linked with decrements in forced expiratory volume in the first second [99] and, according to data from school children living in an e-waste recycling area, the accumulation of $\mathrm{Ni}$ in serum could generate oxidative damage and decreased pulmonary function [19]. A recent study determining the concentrations of $\mathrm{Ni}$ in hair of pregnant women and in fetal placental tissues demonstrated a possible effect of Ni exposure in increasing the occurrence of 
congenital heart defects in offspring [100]. Finally, Ni is a IARC Group 1 carcinogen, and a possible relationship has been suggested between urinary $\mathrm{Ni}$ levels and childhood acute leukemia, secondary to oxidative DNA damage [101].

A recent report showed increased blood levels of heavy metals $(\mathrm{Cr}, \mathrm{Pb}, \mathrm{Cd})$, DNA damage and epigenetic changes (altered DNA methylation) in school age children living within $3 \mathrm{~km}$ around a Chinese waste incinerator [41]. This study confirmed previous evidence reporting higher $\mathrm{Pb}$ and $\mathrm{Cd}$ concentrations in blood samples from adolescents living near a Belgian incinerator than in controls [42]. Unfortunately, however, in both these reports, information on body levels of other metals are lacking.

In our series, children living in exposed or in control area showed similar toenail concentrations of $\mathrm{Cd}, \mathrm{Cr}$, and $\mathrm{Pb}$. However, the proportion of subjects with concentration of these metals below the LOD tended to be higher in the control area. Our results are in line with two previous works reporting, in adults, no associations between living near a municipal solid waste incinerator and blood $\mathrm{Pb}$ and $\mathrm{Cd}$ levels [34,35]. Conversely, higher blood concentrations of $\mathrm{Cr}$ and $\mathrm{Pb}$ have been reported in adults living close to Chinese waste incinerators than in controls, with vegetable ingestion being the main contributor to the total average daily dose of these metals, as compared with Mn [33].

Thus, the possibility exists that site-specific exposure pathways (mainly dependent on dietary habits in rural areas) could influence the internal metal levels in exposed subjects, with consumption of local vegetables grown near incinerators being at risk for specific (i.e., $\mathrm{Cr}, \mathrm{Pb}$ ) body metal accumulation. In fact, in our series of enrolled children (all living in an urban area), consumption of locally grown vegetables was scarce and not linked with metal concentration. In this case, inhalation, rather than ingestion, could be the main exposure route.

In the present study, analysis of covariates suggested a possible influencing effect of previous orthodontic treatments and passive smoke on nail concentration of $\mathrm{Ba}$ (both factors) and $\mathrm{Cu}$ (only passive smoke). However, the role of these confounders seems to be limited, since living in the exposed area was a significant predictor of $\mathrm{Ba}, \mathrm{Ni}, \mathrm{Cu}, \mathrm{Mn}$, and $\mathrm{V}$ nail concentrations after adjusting for all considered covariates. Furthermore, no difference was evident in the distribution of subjects with previous orthodontic treatments and/or passive smoke in the two groups of explored children.

A previous longitudinal study based on dispersion modeling for exposure assessment explored health outcomes in a large cohort of subjects living in the same area examined in our study $(3.5 \mathrm{~km}$ around the two incinerators of Forli). Results showed significant associations between increasing heavy metal exposure and cause-specific mortality: colon cancer in men; all cancer sites, stomach, colon, liver and breast cancer in women; and excess of soft tissue sarcoma in the two sexes combined [54]. These findings point to the existence of an increased health risk in the same urban area in which results from our study have shown a greater internal accumulation of metals in exposed children, as compared with those living in the reference area.

Metals should be considered an indicator of exposure to a complex combination of pollutants generated from waste combustion, including gaseous pollutants, persistent organic pollutants, and a number of other toxic chemicals vehiculated by particulate matter. From this point of view, it should be underlined that cumulative exposure to complex mixtures of chemicals of industrial origin may generate synergistic effects on health [102]. Moreover, possible interactions between multiple and heterogeneous exposures (i.e., industrial pollution, vehicular traffic, contaminated water/food), should overcome the single-pollutant approach with the measurement of the absorbed internal dose of multiple pollutants (the exposome [103]).

Finally, some metals are characterized by a linear dose-response with low-dose effects and no threshold (i.e., $\mathrm{Cu}, \mathrm{Cd}$ ) or by a nonlinear dose-response with low-dose effects (i.e., Ni) [104]. These aspects also generate concern if metals are released in the environment at low concentrations.

Taken together, all these aspects amplify the possibility of health risk in pediatric age, also considering that children are more vulnerable to environmental toxins and have significantly more time, as compared with adults, for developing chronic effects of protracted environmental exposures, including both cancer and noncommunicable diseases. 


\section{Conclusions}

The release of metals from waste incinerators located in an urban area can contribute to human toxicity following chronic exposure, in particular in children.

The present study employed the concentration of metals in toenails as an expression of long-term body accumulation of a wide panel of metals, demonstrating, in children living close to waste incinerators, an increased concentration of specific metals (in particular $\mathrm{Ba}, \mathrm{Mn}, \mathrm{Cu}$, and $\mathrm{V}$ ) potentially leading to an increased health risk.

Measuring the concentration of metals in toenails should be considered a noninvasive and adequate biomonitoring tool and an early warning indicator, which could allow a more realistic and comprehensive analysis of risk assessment as compared with the simple monitoring of environmental pollutants.

Author Contributions: A.D.C.: conceptualization, investigation, methodology, validation, writing the original draft, review \& editing; P.G. and R.R.: conceptualization, funding acquisition (crowdfunding), investigation, writing the original draft, data curation, supervision; G.D. and M.L.: formal analysis. All authors have read and agreed to the published version of the manuscript.

Funding: This research received no external funding.

Conflicts of Interest: The authors declare no conflict of interest.

\section{References}

1. Buonanno, G.; Stabile, L.; Avino, P.; Vanoli, R. Dimensional and chemical characterization of particles at a downwind receptor site of a waste-to-energy plant. Waste Manag. 2010, 30, 1325-1333. [CrossRef]

2. Vilavert, L.; Nadal, M.; Schuhmacher, M.; Domingo, J.L. Concentrations of metals in soils in the neighborhood of a hazardous waste incinerator: Assessment of the temporal trends. Biol. Trace Elem. Res. 2012, 149, 435-442. [CrossRef]

3. Haynes, E.N.; Sucharew, H.; Hilbert, T.J.; Kuhnell, P.; Spencer, A.; Newman, N.C.; Burns, R.; Wright, R.; Parsons, P.J.; Dietrich, K.N. Impact of air manganese on child neurodevelopment in East Liverpool, Ohio. Neurotoxicology 2018, 64, 94-102. [CrossRef]

4. Hu, C.W.; Chao, M.R.; Wu, K.Y.; Chang-Chien, G.P.; Lee, W.J.; Chang, L.W.; Lee, W.S. Characterization of multiple airborne particulate metals in the surroundings of a municipal waste incinerator in Taiwan. Atmos. Environ. 2003, 37, 2845-2852. [CrossRef]

5. Cao, L.; Zeng, J.; Liu, K.; Bao, L.; Li, Y. Characterization and Cytotoxicity of PM<0.2, PM0.2-2.5 and PM2.5-10 around MSWI in Shanghai, China. Int. J. Environ. Res. Public Health 2015, 12, 5076-5089. [CrossRef]

6. Wang, P.; Hu, Y.; Cheng, H. Municipal solid waste (MSW) incineration fly ash as an important source of heavy metal pollution in China. Environ. Pollut. 2019, 252, 461-475. [CrossRef]

7. Pan, Y.; Wu, Z.; Zhou, J.; Zhao, J.; Ruan, X.; Liu, J.; Qian, G. Chemical characteristics and risk assessment of typical municipal solid waste incineration (MSWI) fly ash in China. J. Hazard. Mater. 2013, 261, 269-276. [CrossRef] [PubMed]

8. Li, Y.; Zhang, H.; Shao, L.; Zhou, X.; He, P. Impact of municipal solid waste incineration on heavy metals in the surrounding soils by multivariate analysis and lead isotope analysis. J. Environ. Sci. 2019, 82, 47-56. [CrossRef] [PubMed]

9. Shang, Y.; Wu, M.; Zhou, J.; Zhang, X.; Zhong, Y.; An, J.; Qian, G. Cytotoxicity comparison between fine particles emitted from the combustion of municipal solid waste and biomass. J. Hazard. Mater. 2019, 367, 316-324. [CrossRef]

10. Lou, Z.; Bilitewski, B.; Zhu, N.; Chai, X.; Li, B.; Zhao, Y. Environmental impacts of a large-scale incinerator with mixed MSW of high water content from a LCA perspective. J. Environ. Sci. 2015, 30, 173-179. [CrossRef]

11. Jinhui, L.; Huabo, D.; Pixing, S. Heavy metal contamination of surface soil in electronic waste dismantling area: Site investigation and source-apportionment analysis. Waste Manag. Res. J. Int. Solid Wastes Public Clean. Assoc. Iswa 2011, 29, 727-738. [CrossRef]

12. Zhao, K.; Liu, X.; Xu, J.; Selim, H.M. Heavy metal contaminations in a soil-rice system: Identification of spatial dependence in relation to soil properties of paddy fields. J. Hazard. Mater. 2010, 181, 778-787. [CrossRef] [PubMed] 
13. Carrizales, L.; Razo, I.; Tellez-Hernandez, J.I.; Torres-Nerio, R.; Torres, A.; Batres, L.E.; Cubillas, A.C.; Diaz-Barriga, F. Exposure to arsenic and lead of children living near a copper-smelter in San Luis Potosi, Mexico: Importance of soil contamination for exposure of children. Environ. Res. 2006, 101, 1-10. [CrossRef] [PubMed]

14. Claus Henn, B.; Ettinger, A.S.; Hopkins, M.R.; Jim, R.; Amarasiriwardena, C.; Christiani, D.C.; Coull, B.A.; Bellinger, D.C.; Wright, R.O. Prenatal Arsenic Exposure and Birth Outcomes among a Population Residing near a Mining-Related Superfund Site. Environ. Health Perspect. 2016, 124, 1308-1315. [CrossRef] [PubMed]

15. Haynes, E.N.; Sucharew, H.; Kuhnell, P.; Alden, J.; Barnas, M.; Wright, R.O.; Parsons, P.J.; Aldous, K.M.; Praamsma, M.L.; Beidler, C.; et al. Manganese Exposure and Neurocognitive Outcomes in Rural School-Age Children: The Communities Actively Researching Exposure Study (Ohio, USA). Environ. Health Perspect. 2015, 123, 1066-1071. [CrossRef] [PubMed]

16. Torres-Agustin, R.; Rodriguez-Agudelo, Y.; Schilmann, A.; Solis-Vivanco, R.; Montes, S.; Riojas-Rodriguez, H.; Cortez-Lugo, M.; Rios, C. Effect of environmental manganese exposure on verbal learning and memory in Mexican children. Environ. Res. 2013, 121, 39-44. [CrossRef]

17. Claus Henn, B.; Bellinger, D.C.; Hopkins, M.R.; Coull, B.A.; Ettinger, A.S.; Jim, R.; Hatley, E.; Christiani, D.C.; Wright, R.O. Maternal and Cord Blood Manganese Concentrations and Early Childhood Neurodevelopment among Residents near a Mining-Impacted Superfund Site. Environ. Health Perspect. 2017, 125, 067020. [CrossRef]

18. Pizzino, G.; Irrera, N.; Bitto, A.; Pallio, G.; Mannino, F.; Arcoraci, V.; Aliquo, F.; Minutoli, L.; De Ponte, C.; D'Andrea, P.; et al. Cadmium-Induced Oxidative Stress Impairs Glycemic Control in Adolescents. Oxidative Med. Cell. Longev. 2017, 2017, 6341671. [CrossRef]

19. Zheng, G.; Xu, X.; Li, B.; Wu, K.; Yekeen, T.A.; Huo, X. Association between lung function in school children and exposure to three transition metals from an e-waste recycling area. J. Expo. Sci. Environ. Epidemiol. 2013, 23, 67-72. [CrossRef]

20. Shah, S.; Jeong, K.S.; Park, H.; Hong, Y.C.; Kim, Y.; Kim, B.; Chang, N.; Kim, S.; Kim, Y.; Kim, B.N.; et al. Environmental pollutants affecting children's growth and development: Collective results from the MOCEH study, a multi-centric prospective birth cohort in Korea. Environ. Int. 2020, 137, 105547. [CrossRef]

21. Shao, W.; Liu, Q.; He, X.; Liu, H.; Gu, A.; Jiang, Z. Association between level of urinary trace heavy metals and obesity among children aged 6-19 years: NHANES 1999-2011. Environ. Sci. Pollut. Res. Int. 2017, 24, 11573-11581. [CrossRef]

22. Fan, Y.; Zhang, C.; Bu, J. Relationship between Selected Serum Metallic Elements and Obesity in Children and Adolescent in the U.S. Nutrients 2017, 9, 104. [CrossRef] [PubMed]

23. Rehmani, N.; Zafar, A.; Arif, H.; Hadi, S.M.; Wani, A.A. Copper-mediated DNA damage by the neurotransmitter dopamine and L-DOPA: A pro-oxidant mechanism. Toxicol. In Vitro Int. J. Pub. Assoc. BIBRA 2017, 40, 336-346. [CrossRef] [PubMed]

24. Alemany, S.; Vilor-Tejedor, N.; Bustamante, M.; Alvarez-Pedrerol, M.; Rivas, I.; Forns, J.; Querol, X.; Pujol, J.; Sunyer, J. Interaction between airborne copper exposure and ATP7B polymorphisms on inattentiveness in scholar children. Int. J. Hyg. Environ. Health 2017, 220, 51-56. [CrossRef] [PubMed]

25. Pujol, J.; Fenoll, R.; Macia, D.; Martinez-Vilavella, G.; Alvarez-Pedrerol, M.; Rivas, I.; Forns, J.; Deus, J.; Blanco-Hinojo, L.; Querol, X.; et al. Airborne copper exposure in school environments associated with poorer motor performance and altered basal ganglia. Brain Behav. 2016, 6, e00467. [CrossRef] [PubMed]

26. Lucchini, R.G.; Guazzetti, S.; Renzetti, S.; Conversano, M.; Cagna, G.; Fedrighi, C.; Giorgino, A.; Peli, M.; Placidi, D.; Zoni, S.; et al. Neurocognitive impact of metal exposure and social stressors among schoolchildren in Taranto, Italy. Environ. Health Glob. Access Sci. Source 2019, 18, 67. [CrossRef] [PubMed]

27. Madrigal, J.M.; Persky, V.; Pappalardo, A.; Argos, M. Association of heavy metals with measures of pulmonary function in children and youth: Results from the National Health and Nutrition Examination Survey (NHANES). Environ. Int. 2018, 121, 871-878. [CrossRef]

28. Xu, P.; Chen, Y.; He, S.; Chen, W.; Wu, L.; Xu, D.; Chen, Z.; Wang, X.; Lou, X. A follow-up study on the characterization and health risk assessment of heavy metals in ambient air particles emitted from a municipal waste incinerator in Zhejiang, China. Chemosphere 2019, 246, 125777. [CrossRef]

29. Zumel-Marne, A.; Castano-Vinyals, G.; Kundi, M.; Alguacil, J.; Cardis, E. Environmental Factors and the Risk of Brain Tumours in Young People: A Systematic Review. Neuroepidemiology 2019, 53, 121-141. [CrossRef] 
30. Zhang, H.; Mao, Z.; Huang, K.; Wang, X.; Cheng, L.; Zeng, L.; Zhou, Y.; Jing, T. Multiple exposure pathways and health risk assessment of heavy metal(loid)s for children living in fourth-tier cities in Hubei Province. Environ. Int. 2019, 129, 517-524. [CrossRef]

31. Ranzi, A.; Fustinoni, S.; Erspamer, L.; Campo, L.; Gatti, M.G.; Bechtold, P.; Bonassi, S.; Trenti, T.; Goldoni, C.A.; Bertazzi, P.A.; et al. Biomonitoring of the general population living near a modern solid waste incinerator: A pilot study in Modena, Italy. Environ. Int. 2013, 61, 88-97. [CrossRef]

32. Gatti, M.G.; Bechtold, P.; Campo, L.; Barbieri, G.; Quattrini, G.; Ranzi, A.; Sucato, S.; Olgiati, L.; Polledri, E.; Romolo, M.; et al. Human biomonitoring of polycyclic aromatic hydrocarbonsand metals in the general population residing near the municipal solid waste incinerator of Modena, Italy. Chemosphere 2017, 186, 546-557. [CrossRef] [PubMed]

33. Li, T.; Wan, Y.; Ben, Y.; Fan, S.; Hu, J. Relative importance of different exposure routes of heavy metals for humans living near a municipal solid waste incinerator. Environ. Pollut. 2017, 226, 385-393. [CrossRef]

34. Lee, C.S.; Lim, Y.W.; Kim, H.H.; Yang, J.Y.; Shin, D.C. Exposure to heavy metals in blood and risk perception of the population living in the vicinity of municipal waste incinerators in Korea. Environ. Sci. Pollut. Res. Int. 2012, 19, 1629-1639. [CrossRef] [PubMed]

35. Reis, M.F.; Sampaio, C.; Brantes, A.; Aniceto, P.; Melim, M.; Cardoso, L.; Gabriel, C.; Simao, F.; Miguel, J.P. Human exposure to heavy metals in the vicinity of Portuguese solid waste incinerators-Part 1: Biomonitoring of $\mathrm{Pb}, \mathrm{Cd}$ and $\mathrm{Hg}$ in blood of the general population. Int. J. Hyg. Environ. Health 2007, 210, 439-446. [CrossRef] [PubMed]

36. Wrbitzky, R.; Goen, T.; Letzel, S.; Frank, F.; Angerer, J. Internal exposure of waste incineration workers to organic and inorganic substances. Int. Arch. Occup. Environ. Health 1995, 68, 13-21. [CrossRef] [PubMed]

37. Yaemsiri, S.; Hou, N.; Slining, M.M.; He, K. Growth rate of human fingernails and toenails in healthy American young adults. J. Eur. Acad. Derm. Venereol. 2010, 24, 420-423. [CrossRef]

38. Sukumar, A. Human Nails as a Biomarker of Element Exposure. In Reviews of Environmental Contamination and Toxicology. Reviews of Environmental Contamination and Toxicology; Ware, G.W., Nigg, H.N., Doerge, D.R., Eds.; Springer: New York, NY, USA, 2006; Volume 185.

39. Hopps, H.C. The biologic bases for using hair and nail for analyses of trace elements. Sci. Total Environ. 1977, 7, 71-89. [CrossRef]

40. Gutierrez-Gonzalez, E.; Garcia-Esquinas, E.; de Larrea-Baz, N.F.; Salcedo-Bellido, I.; Navas-Acien, A.; Lope, V.; Gomez-Ariza, J.L.; Pastor, R.; Pollan, M.; Perez-Gomez, B. Toenails as biomarker of exposure to essential trace metals: A review. Environ. Res. 2019, 179, 108787. [CrossRef]

41. Xu, P.; Chen, Z.; Chen, Y.; Feng, L.; Wu, L.; Xu, D.; Wang, X.; Lou, X.; Lou, J. Body burdens of heavy metals associated with epigenetic damage in children living in the vicinity of a municipal waste incinerator. Chemosphere 2019, 229, 160-168. [CrossRef]

42. Schroijen, C.; Baeyens, W.; Schoeters, G.; Den Hond, E.; Koppen, G.; Bruckers, L.; Nelen, V.; Van De Mieroop, E.; Bilau, M.; Covaci, A.; et al. Internal exposure to pollutants measured in blood and urine of Flemish adolescents in function of area of residence. Chemosphere 2008, 71, 1317-1325. [CrossRef]

43. Reis, M.F.; Sampaio, C.; Brantes, A.; Aniceto, P.; Melim, M.; Cardoso, L.; Gabriel, C.; Simao, F.; Miguel, J.P. Human exposure to heavy metals in the vicinity of Portuguese solid waste incinerators-Part 3: Biomonitoring of $\mathrm{Pb}$ in blood of children under the age of 6 years. Int. J. Hyg. Environ. Health 2007, 210, 455-459. [CrossRef] [PubMed]

44. Llobet, J.M.; Falco, G.; Casas, C.; Teixido, A.; Domingo, J.L. Concentrations of arsenic, cadmium, mercury, and lead in common foods and estimated daily intake by children, adolescents, adults, and seniors of Catalonia, Spain. J. Agric. Food Chem. 2003, 51, 838-842. [CrossRef] [PubMed]

45. Joas, R.; Casteleyn, L.; Biot, P.; Kolossa-Gehring, M.; Castano, A.; Angerer, J.; Schoeters, G.; Sepai, O.; Knudsen, L.E.; Joas, A.; et al. Harmonised human biomonitoring in Europe: Activities towards an EU HBM framework. Int. J. Hyg. Environ. Health 2012, 215, 172-175. [CrossRef] [PubMed]

46. Esteban, M.; Castano, A. Non-invasive matrices in human biomonitoring: A review. Environ. Int. 2009, 35, 438-449. [CrossRef] [PubMed]

47. Slotnick, M.J.; Nriagu, J.O.; Johnson, M.M.; Linder, A.M.; Savoie, K.L.; Jamil, H.J.; Hammad, A.S. Profiles of trace elements in toenails of Arab-Americans in the Detroit area, Michigan. Biol. Trace Elem. Res. 2005, 107, 113-126. [CrossRef] 
48. Da Silveira Fleck, A.; Carneiro, M.F.; Barbosa, F., Jr.; Amantea, S.L.; Rhoden, C.R. The use of tree barks and human fingernails for monitoring metal levels in urban areas of different population densities of Porto Alegre, Brazil. Environ. Sci. Pollut. Res. Int. 2017, 24, 2433-2441. [CrossRef]

49. Menezes-Filho, J.A.; Carvalho, C.F.; Rodrigues, J.L.G.; Araujo, C.F.S.; Dos Santos, N.R.; Lima, C.S.; Bandeira, M.J.; Marques, B.L.S.; Anjos, A.L.S.; Bah, H.A.F.; et al. Environmental Co-Exposure to Lead and Manganese and Intellectual Deficit in School-Aged Children. Int. J. Environ. Res. Public Health 2018, 15, 2418. [CrossRef]

50. Rodrigues, J.L.G.; Araujo, C.F.S.; Dos Santos, N.R.; Bandeira, M.J.; Anjos, A.L.S.; Carvalho, C.F.; Lima, C.S.; Abreu, J.N.S.; Mergler, D.; Menezes-Filho, J.A. Airborne manganese exposure and neurobehavior in school-aged children living near a ferro-manganese alloy plant. Environ. Res. 2018, 167, 66-77. [CrossRef]

51. Carneiro, M.F.; Grotto, D.; Batista, B.L.; Rhoden, C.R.; Barbosa, F., Jr. Background values for essential and toxic elements in children's nails and correlation with hair levels. Biol. Trace Elem. Res. 2011, 144, 339-350. [CrossRef]

52. Hunter, D.J.; Morris, J.S.; Chute, C.G.; Kushner, E.; Colditz, G.A.; Stampfer, M.J.; Speizer, F.E.; Willett, W.C. Predictors of selenium concentration in human toenails. Am. J. Epidemiol. 1990, 132, 114-122. [CrossRef]

53. Slotnick, M.J.; Nriagu, J.O. Validity of human nails as a biomarker of arsenic and selenium exposure: A review. Environ. Res. 2006, 102, 125-139. [CrossRef] [PubMed]

54. Ranzi, A.; Fano, V.; Erspamer, L.; Lauriola, P.; Perucci, C.A.; Forastiere, F. Mortality and morbidity among people living close to incinerators: A cohort study based on dispersion modeling for exposure assessment. Environ. Health 2011, 10, 22. [CrossRef] [PubMed]

55. Elliott, P.; Hills, M.; Beresford, J.; Kleinschmidt, I.; Jolley, D.; Pattenden, S.; Rodrigues, L.; Westlake, A.; Rose, G. Incidence of cancers of the larynx and lung near incinerators of waste solvents and oils in Great Britain. Lancet 1992, 339, 854-858. [CrossRef]

56. Forastiere, F.; Badaloni, C.; de Hoogh, K.; von Kraus, M.K.; Martuzzi, M.; Mitis, F.; Palkovicova, L.; Porta, D.; Preiss, P.; Ranzi, A.; et al. Health impact assessment of waste management facilities in three European countries. Environ. Health Glob. Access Sci. Source 2011, 10, 53. [CrossRef] [PubMed]

57. Michelozzi, P.; Fusco, D.; Forastiere, F.; Ancona, C.; Dell'Orco, V.; Perucci, C.A. Small area study of mortality among people living near multiple sources of air pollution. Occup. Environ. Med. 1998, 55, 611-615. [CrossRef]

58. Barbosa, F., Jr.; Tanus-Santos, J.E.; Gerlach, R.F.; Parsons, P.J. A critical review of biomarkers used for monitoring human exposure to lead: Advantages, limitations, and future needs. Environ. Health Perspect. 2005, 113, 1669-1674. [CrossRef]

59. Gault, A.G.; Rowland, H.A.; Charnock, J.M.; Wogelius, R.A.; Gomez-Morilla, I.; Vong, S.; Leng, M.; Samreth, S.; Sampson, M.L.; Polya, D.A. Arsenic in hair and nails of individuals exposed to arsenic-rich groundwaters in Kandal province, Cambodia. Sci. Total Environ. 2008, 393, 168-176. [CrossRef]

60. Coelho, P.; Costa, S.; Costa, C.; Silva, S.; Walter, A.; Ranville, J.; Pastorinho, M.R.; Harrington, C.; Taylor, A.; Dall'Armi, V.; et al. Biomonitoring of several toxic metal(loid)s in different biological matrices from environmentally and occupationally exposed populations from Panasqueira mine area, Portugal. Environ. Geochem. Health 2014, 36, 255-269. [CrossRef]

61. Butler, L.; Gennings, C.; Peli, M.; Borgese, L.; Placidi, D.; Zimmerman, N.; Hsu, H.L.; Coull, B.A.; Wright, R.O.; Smith, D.R.; et al. Assessing the contributions of metals in environmental media to exposure biomarkers in a region of ferroalloy industry. J. Expo. Sci. Environ. Epidemiol. 2019, 29, 674-687. [CrossRef]

62. Wilhelm, M.; Lombeck, I.; Ohnesorge, F.K. Cadmium, copper, lead and zinc concentrations in hair and toenails of young children and family members: A follow-up study. Sci. Total Environ. 1994, 141, 275-280. [CrossRef]

63. Wickre, J.B.; Folt, C.L.; Sturup, S.; Karagas, M.R. Environmental exposure and fingernail analysis of arsenic and mercury in children and adults in a Nicaraguan gold mining community. Arch. Environ. Health 2004, 59, 400-409. [CrossRef] [PubMed]

64. Oyoo-Okoth, E.; Admiraal, W.; Osano, O.; Ngure, V.; Kraak, M.H.; Omutange, E.S. Monitoring exposure to heavy metals among children in Lake Victoria, Kenya: Environmental and fish matrix. Ecotoxicol. Environ. Saf. 2010, 73, 1797-1803. [CrossRef] [PubMed]

65. Carneiro, M.F.; Rhoden, C.R.; Amantea, S.L.; Barbosa, F., Jr. Low concentrations of selenium and zinc in nails are associated with childhood asthma. Biol. Trace Elem. Res. 2011, 144, 244-252. [CrossRef] [PubMed] 
66. Chanpiwat, P.; Himeno, S.; Sthiannopkao, S. Arsenic and Other Metals' Presence in Biomarkers of Cambodians in Arsenic Contaminated Areas. Int. J. Environ. Res. Public Health 2015, 12, 14285-14300. [CrossRef] [PubMed]

67. Grashow, R.; Zhang, J.; Fang, S.C.; Weisskopf, M.G.; Christiani, D.C.; Cavallari, J.M. Toenail metal concentration as a biomarker of occupational welding fume exposure. J. Occup. Environ. Hyg. 2014, 11, 397-405. [CrossRef]

68. Sanches, T.P.; Saiki, M. Establishing a protocol for element determinations in human nail clippings by neutron activation analysis. In Proceedings of the 2011 International Nuclear Atlantic Conference-INAC 2011, Belo Horizonte, Brazil, 24-28 October 2011.

69. Lubin, J.H.; Colt, J.S.; Camann, D.; Davis, S.; Cerhan, J.R.; Severson, R.K.; Bernstein, L.; Hartge, P. Epidemiologic evaluation of measurement data in the presence of detection limits. Environ. Health Perspect. 2004, 112, 1691-1696. [CrossRef]

70. Tobin, J. Estimation of Relationships for Limited Dependent Variables. Econometrica 1958, 26, $24-36$. [CrossRef]

71. Rodrigues, J.L.G.; Bandeira, M.J.; Araujo, C.F.S.; Dos Santos, N.R.; Anjos, A.L.S.; Koin, N.L.; Pereira, L.C.; Oliveira, S.S.P.; Mergler, D.; Menezes-Filho, J.A. Manganese and lead levels in settled dust in elementary schools are correlated with biomarkers of exposure in school-aged children. Environ. Pollut. 2018, 236, 1004-1013. [CrossRef]

72. Laohaudomchok, W.; Lin, X.; Herrick, R.F.; Fang, S.C.; Cavallari, J.M.; Christiani, D.C.; Weisskopf, M.G. Toenail, blood, and urine as biomarkers of manganese exposure. J. Occup. Environ. Med. 2011, 53, 506-510. [CrossRef]

73. Adair, B.M.; Hudgens, E.E.; Schmitt, M.T.; Calderon, R.L.; Thomas, D.J. Total arsenic concentrations in toenails quantified by two techniques provide a useful biomarker of chronic arsenic exposure in drinking water. Environ. Res. 2006, 101, 213-220. [CrossRef]

74. Hughes, M.F. Biomarkers of exposure: A case study with inorganic arsenic. Environ. Health Perspect. 2006, 114, 1790-1796. [CrossRef] [PubMed]

75. Hassani, H.; Golbabaei, F.; Shirkhanloo, H.; Tehrani-Doust, M. Relations of biomarkers of manganese exposure and neuropsychological effects among welders and ferroalloy smelters. Ind. Health 2016, 54, 79-86. [CrossRef] [PubMed]

76. Lucas, E.L.; Bertrand, P.; Guazzetti, S.; Donna, F.; Peli, M.; Jursa, T.P.; Lucchini, R.; Smith, D.R. Impact of ferromanganese alloy plants on household dust manganese levels: Implications for childhood exposure. Environ. Res. 2015, 138, 279-290. [CrossRef] [PubMed]

77. Berasaluce, M.; Mondaca, P.; Schuhmacher, M.; Bravo, M.; Sauve, S.; Navarro-Villarroel, C.; Dovletyarova, E.A.; Neaman, A. Soil and indoor dust as environmental media of human exposure to $\mathrm{As}, \mathrm{Cd}, \mathrm{Cu}$, and $\mathrm{Pb}$ near a copper smelter in central Chile. J. Trace Elem. Med. Biol. Organ Soc. Miner. Trace Elem. 2019, 54, 156-162. [CrossRef] [PubMed]

78. Pearce, D.C.; Dowling, K.; Gerson, A.R.; Sim, M.R.; Sutton, S.R.; Newville, M.; Russell, R.; McOrist, G. Arsenic microdistribution and speciation in toenail clippings of children living in a historic gold mining area. Sci. Total Environ. 2010, 408, 2590-2599. [CrossRef] [PubMed]

79. Ab Razak, N.H.; Praveena, S.M.; Hashim, Z. Toenail as a biomarker of heavy metal exposure via drinking water: A systematic review. Rev. Environ. Health 2015, 30, 1-7. [CrossRef]

80. Liu, L.; Urch, B.; Szyszkowicz, M.; Evans, G.; Speck, M.; Van Huang, A.; Leingartner, K.; Shutt, R.H.; Pelletier, G.; Gold, D.R.; et al. Metals and oxidative potential in urban particulate matter influence systemic inflammatory and neural biomarkers: A controlled exposure study. Environ. Int. 2018, 121, 1331-1340. [CrossRef]

81. Goulle, J.P.; Saussereau, E.; Mahieu, L.; Bouige, D.; Groenwont, S.; Guerbet, M.; Lacroix, C. Application of inductively coupled plasma mass spectrometry multielement analysis in fingernail and toenail as a biomarker of metal exposure. J. Anal. Toxicol. 2009, 33, 92-98. [CrossRef]

82. Mohmand, J.; Eqani, S.A.; Fasola, M.; Alamdar, A.; Mustafa, I.; Ali, N.; Liu, L.; Peng, S.; Shen, H. Human exposure to toxic metals via contaminated dust: Bio-accumulation trends and their potential risk estimation. Chemosphere 2015, 132, 142-151. [CrossRef]

83. Rovira, J.; Mari, M.; Nadal, M.; Schuhmacher, M.; Domingo, J.L. Environmental monitoring of metals, PCDD/Fs and PCBs as a complementary tool of biological surveillance to assess human health risks. Chemosphere 2010, 80, 1183-1189. [CrossRef] 
84. Elder, A.; Gelein, R.; Silva, V.; Feikert, T.; Opanashuk, L.; Carter, J.; Potter, R.; Maynard, A.; Ito, Y.; Finkelstein, J.; et al. Translocation of inhaled ultrafine manganese oxide particles to the central nervous system. Environ. Health Perspect. 2006, 114, 1172-1178. [CrossRef] [PubMed]

85. Rovira, J.; Nadal, M.; Schuhmacher, M.; Domingo, J.L. Concentrations of trace elements and PCDD/Fs around a municipal solid waste incinerator in Girona (Catalonia, Spain). Human health risks for the population living in the neighborhood. Sci. Total Environ. 2018, 630, 34-45. [CrossRef] [PubMed]

86. Qayyum, M.A.; Shah, M.H. Disparities in Trace Metal Levels in Hodgkin/Non-Hodgkin Lymphoma Patients in Comparison with Controls. Biol. Trace Elem. Res. 2020, 194, 34-47. [CrossRef] [PubMed]

87. Theophanides, T.; Anastassopoulou, J. Copper and carcinogenesis. Crit. Rev. Oncol. Hematol. 2002, 42, 57-64. [CrossRef]

88. Yakinci, C.; Pac, A.; Kucukbay, F.Z.; Tayfun, M.; Gul, A. Serum zinc, copper, and magnesium levels in obese children. Acta Paediatr. Jpn. Overseas Ed. 1997, 39, 339-341. [CrossRef]

89. Lima, S.C.; Arrais, R.F.; Sales, C.H.; Almeida, M.G.; de Sena, K.C.; Oliveira, V.T.; de Andrade, A.S.; Pedrosa, L.F. Assessment of copper and lipid profile in obese children and adolescents. Biol. Trace Elem. Res. 2006, 114, 19-29. [CrossRef]

90. Kravchenko, J.; Darrah, T.H.; Miller, R.K.; Lyerly, H.K.; Vengosh, A. A review of the health impacts of barium from natural and anthropogenic exposure. Environ. Geochem. Health 2014, 36, 797-814. [CrossRef]

91. Poddalgoda, D.; Macey, K.; Assad, H.; Krishnan, K. Development of biomonitoring equivalents for barium in urine and plasma for interpreting human biomonitoring data. Regul. Toxicol. Pharm. 2017, 86, 303-311. [CrossRef]

92. Ohgami, N.; Mitsumatsu, Y.; Ahsan, N.; Akhand, A.A.; Li, X.; Iida, M.; Yajima, I.; Naito, M.; Wakai, K.; Ohnuma, S.; et al. Epidemiological analysis of the association between hearing and barium in humans. J. Expo. Sci. Environ. Epidemiol. 2016, 26, 488-493. [CrossRef]

93. Zhang, N.; Liu, Z.; Tian, X.; Chen, M.; Deng, Y.; Guo, Y.; Li, N.; Yu, P.; Yang, J.; Zhu, J. Barium exposure increases the risk of congenital heart defects occurrence in offspring. Clin. Toxicol. 2018, 56, 132-139. [CrossRef]

94. Masironi, R.; Koirtyohann, S.R.; Pierce, J.O.; Schamschula, R.G. Calcium content of river water, trace element concentrations in toenails, and blood pressure in village populations in New Guinea. Sci. Total Environ. 1976, 6, 41-53. [CrossRef]

95. Rakovic, M.; Foltynova, V.; Pilecka, N.; Glagolicova, A.; Kucera, J. Assessment of metals and metalloids in skin derivatives of volunteers from capital city of Prague, Czech Republic. Sbornik Lekarsky 1997, 98, 107-114. [PubMed]

96. Swietlicki, E.; Kemp, K.; Wahlin, P.; Bartnicki, J.; Jalkanen, L. Source-receptor relationships for heavy metals in the European atmosphere. Nucl. Instrum. Meth. B 1999, 150, 322-332. [CrossRef]

97. Rahn, K.A.; Lowenthal, D.H. Elemental tracers of distant regional pollution aerosols. Science 1984, 223, 132-139. [CrossRef] [PubMed]

98. Wang, X.; Sato, T.; Xing, B. Size distribution and anthropogenic sources apportionment of airborne trace metals in Kanazawa, Japan. Chemosphere 2006, 65, 2440-2448. [CrossRef] [PubMed]

99. Eeftens, M.; Hoek, G.; Gruzieva, O.; Molter, A.; Agius, R.; Beelen, R.; Brunekreef, B.; Custovic, A.; Cyrys, J.; Fuertes, E.; et al. Elemental composition of particulate matter and the association with lung function. Epidemiology 2014, 25, 648-657. [CrossRef]

100. Zhang, N.; Chen, M.; Li, J.; Deng, Y.; Li, S.L.; Guo, Y.X.; Li, N.; Lin, Y.; Yu, P.; Liu, Z.; et al. Metal nickel exposure increase the risk of congenital heart defects occurrence in offspring: A case-control study in China. Medicine 2019, 98, e15352. [CrossRef]

101. Yang, Y.; Jin, X.M.; Yan, C.H.; Tian, Y.; Tang, J.Y.; Shen, X.M. Urinary level of nickel and acute leukaemia in Chinese children. Toxicol. Ind. Health 2008, 24, 603-610. [CrossRef]

102. Carpenter, D.O.; Arcaro, K.; Spink, D.C. Understanding the human health effects of chemical mixtures. Environ. Health Perspect. 2002, 110 (Suppl. 1), 25-42. [CrossRef] 
103. Wild, C.P. The exposome: From concept to utility. Int. J. Epidemiol. 2012, 41, 24-32. [CrossRef]

104. Goodson, W.H., 3rd; Lowe, L.; Carpenter, D.O.; Gilbertson, M.; Manaf Ali, A.; Lopez de Cerain Salsamendi, A.; Lasfar, A.; Carnero, A.; Azqueta, A.; Amedei, A.; et al. Assessing the carcinogenic potential of low-dose exposures to chemical mixtures in the environment: The challenge ahead. Carcinogenesis 2015, 36 (Suppl. 1), S254-S296. [CrossRef] 